Gerhard Grohs and Bassam Tibi (eds.)*

Zur Soziologie der Dekolonisation

Fischer Verlag, Frankfurt (1973), Pp. 299

As the editors of this book state in their forward, there are two ways of interpreting decolonization: one may consider it as the acquisition of legal sovereignty by the former colonial territories, in which case the final recognition of statehood marks the end of this process; one may take the other view, that adopted by the contributors to this volume, that decolonization is the process whereby the dependent territories attempt to end their dependence on the colonial powers by transforming their economic, social and political structures and by breaking away from the peripheral position they occupy in the world capitalist system. In this sense, the grant of independence is not the terminal point but rather, the starting point of an arduous task.

By adopting the second conception of decolonization and by deriving inspiration from Frantz Fanon's "Les damnés la terre" (1961), the contributors to this volume clearly and consciously distinguish themselves from the usual West German writers on Africa: they conceive their work not as just another addition to the literature on Africa, to be discussed by specialists (with all the hypocrisy about "Wertfreiheit") and put away; they seek to reach a wider public which is interested in understanding the efforts of the African states to free themselves from foreign domination in all aspects of their society.

Part I which is devoted to North Africa consists of two essays by Bassam Tibi on Algeria and Tunisia. Algeria has had the reputation of being a revolutionary country. The bloody war of liberation, resulting mainly from the resistance of the French colonialists to the demand for independence and the writings of Fanon, based on his experience in Algeria, have contributed to this reputation. Tibi shows convincingly that this reputation is based on a myth. The overthrow of Ben Bella, motivated by his attempts at socialism, ushered in a period of reaction. Many of those who had fought in the war of liberation felt entitled to some reward: the army used its power to distribute land to its members; trade unions were suppressed or brought under control; students who demanded the restoration of democratic rights were silenced; programmes of arabization were used mainly to thwart attempts at secularization and socialism. Tibi explains in detail how a revolutionary movement, FLN, developed in independent Algeria into an authoritarian ruling party, and how an anti-colonialist philosophy was transformed into a mystical conservative ideology. Frantz Fanon would have found it difficult to live in the country for which he did so much.

Tunisia has not fared much better than Algeria in the postcolonial period. The Tunisian leadership, despite its proclamations on socialism remains essentially what it has always been: a leadership of petty-bourgeois nationalists whose main concerns do not extend beyond that of their own class interests. However, as Tibi correctly points out (p. 112), some members of this class do not remain forever bound to their class interests; they join the ranks of the working class. But the removal of Ben Salah, shows that the national bourgeoisie would not tolerate even a mild socialist experiment. Tibi draws from this the same conclusion as many

\footnotetext{
*Vgl. schon die auf Sambia beschränkte Besprechung von Schroeder-Hohenwarth in VRU 74 S. 351.
} 
others have done: that the so-called third way, of ten put forward by nationalists in the exploited countries as an alternative to revolutionary socialism is but a deception. The third way only works so long as it does not seriously try to change the existing social and economic structures.

Part II of this book is devoted to East Africa and consists of studies by Gerhard Grohs on Tanzania, Karl Wohlmuth on Zambia and Ute Luig on Uganda.

Gerhard Grohs examines Tanzania's experiment at socialism, the difficulties and contradictions faced by Nyerere and concludes that Tanzania has the most well conceived model of socialism in Africa. Here too, the interests of the various elites in the party and the civil service prevent any progress. Indeed, some members of the national bourgeoisie are very much attracted by Kenya's capitalism.

Wohlmuth's exemplary study shows another case of the role of the national bourgeoisie in Africa. Since independence, Zambia has made some progress in Africanization i. e. the replacement of foreign personnel but the country is still heavily dependent on foreign personnel and above all, on international capitalism which still controls Zambia's copper. The elite have not made any serious effort to transform the colonial economic and social structures. The vast majority of Zambians still live in poor conditions despite the vast mineral resources of the country. Kaunda's philosophy of Humanism has been a failure (163-168). This integretive ideology has been ineffective because it presupposes a socio-economic situation (harmonious development of social groups, possibility of preventing class formation by emphasizing traditional values) which does not correspond to the actual situation in the country. The humanist ideology ignores the relations of production and emphasizes the relations of the individual to God and to the traditional society. Nor is this an effective weapon against capitalism.

Ute Luig shows that neither Obote nor Amin has been able to solve the contradictions resulting from colonial rule in Uganda. Although Amin's racialist policy may have been popular, it benefits in the end only part of the national bourgeoisie.

Part III which deals with West and Equatorial Africa confirms the experience in North and East Africa: an unfinished process from which only the national bourgeoisie has profited. Tetzlaf documents this failure in Ghana although he emphasizes that the failure of the C.P.P. government should not be sought in the diminishing charisma of Nkrumah nor in his method of rule. The intrigue of international capital (pp. 238-239) and the resistance of the Ghanaian elite to any structural changes must also be remembered.

The Peoples Republic of Congo is the only country in Africa which openly espouses the theory of Marxism-Leninism,attempts to build a society on the basis of marxist socialism and thereby avoids the nebulous theory of African socialism. But whether the experiment would succeed or not, and especially whether the political party would gain ascendency over the army, remains to be seen.

The general conclusion which can be drawn from the various contributions to this book is that independence has benefited mainly the national bourgeoisie. The question which arises is how the wealth of these countries can be made available to other classes. In other words how does one go beyond the present beneficiaries? Should one eliminate them as Mahjemout Diop suggests in his "Classes et 
Idéologies de Classe au Sénégal” (1963, 51-67)? As we know, Fanon had nothing but contempt for this class which he considered to be agents of international capitalism. But he recognised that part of this class, i. e. the intellectuals may under certain conditions side with the masses (Les damnés de la terre, 113-135). A similar position has been expressed by Kwame Nkrumah in his "Class Struggle in Africa" (1970), 55. Varga's view on the bourgeoisie would seem to be fairly realistic (pp. 276). As he states, however corrupt the African bourgeoisie may be (and which bourgeoisie does not contain corrupt elements?) it possesses skills which, for the time being at least, are needed by the new states. The schools, hospitals, the administration and various sectors of the modern economy could not function for long without the help of this class; furthermore, not all the so-called privileged classes are committed to capitalism. Varga points out that many of the African intellectuals who have had a prolonged contact with capitalism, especially in Europe and North America, return home convinced socialists.

Decolonization in Africa has not been an easy process nor is it any where near completion. The contributors to this volume should be congratulated for raising the level of discussion on African problems by drawing attention to the serious obstacles, both in and outside Africa which render the process of emancipation particularly difficult. However justified the criticisms against the African bourgeoisie may be, one is tempted to say with Yves Bénot, at least as far as the instellectuals are concerned, "ils sont le seul levier possible de transformations radicales qui briseraient enfin le cercle du néocolonialisme" ("Idéologies des indépendances africaines"), 1969, p. 17.

Kwame Opoku

\section{Klaus Heinemann}

Soziale Sicherung der Arbeitnehmer in der Indischen Union

Sozialpolitische Schriften Heft 27, Duncker \& Humblot, Berlin 1971, 212 S., $39,60 \mathrm{DM}$.

Eine der Grundaufgaben des Staates ist die Schaffung von Sicherheit. Viele Staatstheoretiker gehen sogar davon aus, daß das Streben nach Sicherheit die leitende Kraft für die Staatsbildung überhaupt sei. Jahrhundertelang war aber der Sicherheitsbegriff ein außenpolitischer. Der Staat sollte den einzelnen vor äußeren Angriffen schützen. Erst der Moderne Staat hat die ursprünglich anderen Institutionen zukommenden Funktionen der sozialen Sicherung übernommen. Die Familie, die Zunft, die irgendwie sonst unterhalb der Staatlichkeit gebildete Vereinigung übernahm und übernimmt in zahlreichen Staaten auch heute noch die soziale Sicherung ihrer Mitglieder. Jedoch sind diese Subsysteme immer weniger geeignet, den Schutz vor Arbeitslosigkeit, Einkommenslosigkeit und in letzter Konsequenz vor dem Verhungern zu leisten. Immer speziellere Arbeitsteilung und die Auflösung der traditionellen Sozialstruktur gestatten es kaum noch, das Beschäftigungs- und Krankheitsrisiko durch Kleingruppen aufzufangen. Diese Problematik verschärft sich für Indien noch unermeßlich durch die rasante Bevölkerungszunahme, die zu einer solchen Knappheit der Resourcen führt, daß die traditionellen Verteilungsmechanismen leerlaufen, weil es nichts zu verteilen gibt.

Auch in Indien versucht man seit geraumer Zeit, eine allgemeine Sozialversicherung aufzubauen. Dieser Thematik ist das Buch von Heinemann gewidmet. Es stellt 